\section{Fruit Maturity and Quality of Splice- grafted and One-cotyledon Grafted Watermelon}

\author{
Pinki Devi \\ Department of Horticulture, Washington State University, Northwestern \\ Washington Research and Extension Center, 16650 State Route 536, Mount \\ Vernon, WA 98273
}

\section{Scott Lukas}

Department of Horticulture, Oregon State University, Hermiston Agricultural Research and Extension Center, 2121 South 1st Street, Hermiston, OR 97838

\section{Carol A. Miles}

Department of Horticulture, Washington State University, Northwestern Washington Research and Extension Center, 16650 State Route 536, Mount Vernon, WA 98273

Additional index words. antitranspirant, harvest, regrowth, rootstock, sucrose, survival

\begin{abstract}
Splice grafting with both cotyledons removed from the rootstock may significantly increase watermelon [Citrullus lanatus (Thunb.) Matsum. and Nakai] grafting efficiency, eliminate rootstock regrowth, and reduce costs of watermelon transplant production. We evaluated the efficacy of antitranspirant and sucrose treatments on the survival of splicegrafted transplants and assessed the effects of grafting method and rootstocks on fruit yield and quality. First, in a greenhouse experiment, four commercial antitranspirants, applied to rootstock seedlings before splice grafting, increased transplant survival 21 days after grafting (DAG) from $7 \%$ to $35 \%$ to $68 \%(P<0.0001)$. In a second greenhouse experiment, survival of splice-grafted seedlings was $91 \%$ for plants that received $2 \%$ sucrose solution + antitranspirant, compared with $67 \%$ for plants receiving $2 \%$ sucrose alone and $25 \%$ for plants that received only water $(P<0.0001)$. Finally, in a field experiment we compared splice- vs. one-cotyledon grafting with two rootstocks ('Shintosa Camelforce' and 'Tetsukabuto') vs. nongrafted plants. At 54 days after transplanting (DAT), survival of all grafted transplants averaged $96 \%$ with a plant vigor rating of $7.7 / 10(10=$ most vigorous $)$, compared with $84 \%$ survival (5.8/10 vigor rating) for nongrafted transplants. Flowering was delayed by an average of 2 days for splice-grafted watermelon (37 DAT) vs. one-cotyledon grafted and nongrafted plants $(P<0.0001)$, but harvest date was the same for all treatments $(70 \mathrm{DAT})$. Fruit were harvested 0,7 , and 14 days after fruit reached physiological maturity, and there was no difference in total yield or fruit quality between grafted and nongrafted treatments, with two exceptions. Fruit with splice-grafted 'Shintosa Camelforce' rootstock had the firmest flesh (8.2 N) compared with nongrafted transplants $(5.3 \mathrm{~N})$, and lycopene increased from $16.7 \mu \mathrm{g} \cdot \mathrm{g}^{-1}$ at physiological maturity to as high as $31.4 \mu \mathrm{g} \cdot \mathrm{g}^{-1}$ when harvested 7 days after physiological maturity $(P=0.0002)$. These results indicate that application of sucrose with antitranspirant to rootstock seedlings before grafting can increase the survival of splicegrafted watermelon, and splice-grafted watermelon perform similarly to one-cotyledon grafted and nongrafted watermelon plants in field production.
\end{abstract}

Received for publication 3 Apr. 2020. Accepted for publication 5 May 2020.

Published online 10 June 2020.

Funding support was provided by the U.S. Department of Agriculture National Institute of Food and Agriculture Specialty Crop Research Initiative Grant 2011-51181-30963, the Pacific Northwest Vegetable Association, the OSU Agricultural Research Foundation, and NIFA Hatch project 1017286. Technical assistance provided by Patricia Kreider, Edward Scheenstra, and Logan Clark is gratefully acknowledged.

C.A.M. is the corresponding author. E-mail: milesc@ wsu.edu.

This is an open access article distributed under the CC BY-NC-ND license (https://creativecommons. org/licenses/by-nc-nd/4.0/). meristem tissue from the base of the remaining cotyledon (Dabirian and Miles, 2017a; Hassell et al., 2008; Memmott and Hassell, 2010). Yet rootstock bud meristem tissue may be only partially removed because it is difficult to see, and rootstock regrowth, sometimes referred to as "suckering," will occur (Fig. 1) (Bisognin et al., 2005; Guan and Zhao, 2015; Hassell et al., 2008; Miles et al., 2017). Rootstock regrowth is a major concern for grafted watermelon because it can cause graft failure or a decrease in yield due to competition with the scion for water and nutrients (Daley and Hassell, 2014; Guan and Zhao, 2015). If the regrowth is manually removed at the transplant stage, labor is still required to scout and remove further regrowth in the field (Choi et al., 2002; Dabirian and Miles, 2017a; Lee and Oda, 2003). Chemical removal of rootstock meristem tissue has been achieved with fatty alcohol solution; however, labor is required for the application, and damage to seedlings can occur (Daley and Hassell, 2014). To produce the large number of watermelon transplants required by growers in the United States, the grafting process needs to become more efficient (Kubota et al., 2008).

Splice grafting where both cotyledons are removed from the rootstock is the fastest, most efficient grafting method and is the most commonly used technique for producing large numbers of solanaceous grafted plants because it is possible to graft plants two to three times faster than other methods (Oda, 2007; Rivard et al., 2010). By cutting the rootstock below the cotyledons, meristematic tissue is completely removed, and the potential for rootstock regrowth can be essentially eliminated. However, the success rate of splice-grafted watermelon is low due to limited carbohydrate levels in the rootstock when both the cotyledons are removed (Davis et al., 2008; Memmott and Hassell, 2010). The role of carbohydrates in vegetable grafting has not been extensively reviewed, but at the time of grafting, the growing shoot and roots are the primary carbohydrate sinks. Dabirian and Miles (2017a) showed that drench applications of sucrose solution to rootstock seedlings before watermelon grafting can increase grafting success when both cotyledons are removed from the rootstock by splice grafting. Survival (\%) of splicegrafted watermelon seedlings 21 DAG was the greatest for plants that received $2 \%$ and $3 \%$ sucrose solution ( $89 \%$ and $82 \%$ survival, respectively), followed by plants that received $1 \%$ sucrose solution ( $78 \%$ survival), and was the lowest for plants that received water ( $58 \%$ survival). Sucrose application increased starch levels in rootstock seedlings, which was rated using a modified version of the Cornell starch-iodine starch staining test. Starch level was highest for plants that received 3\% sucrose solution ( $71 \%$ ), followed by plants that received $2 \%$ sucrose solution $(52 \%), 1 \%$ sucrose solution $(29 \%)$, and water $(6 \%)$. Although the scion has stored carbohydrates in the cotyledons and the leaves, these are not able to reach the rootstock until 
A

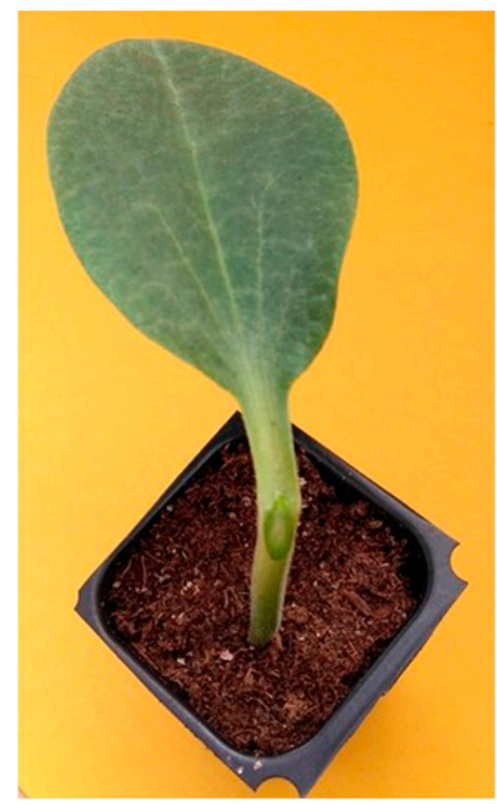

B

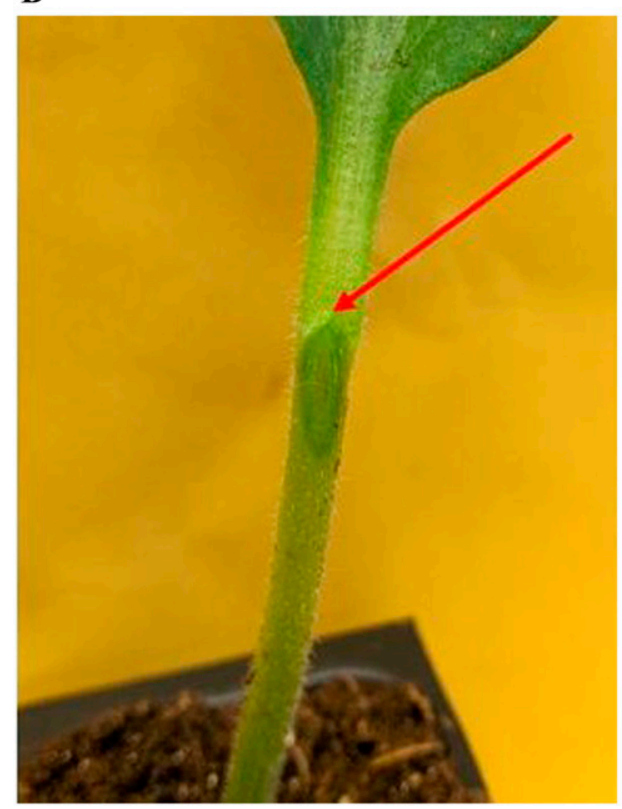

C

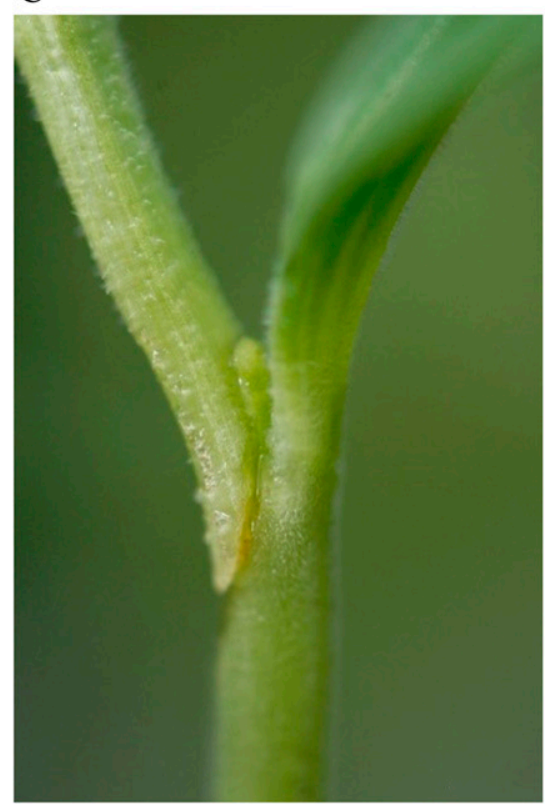

Fig. 1. The meristem tissue lies below the axillary bud at the base of the cotyledon (A and B); if it is not completely removed, the rootstock will regrow (C).

cellular and vascular connections are restored (Melnyk, 2017). Removing both cotyledons from the rootstock delays the time required for callus formation and reduces watermelon grafting success, suggesting a correlation between carbohydrate status in the rootstock stem and seedling survival in grafted watermelon (Dabirian and Miles, 2017a).

Another issue affecting the survival of grafted watermelon transplants is the susceptibility of the plant to desiccation following the grafting procedure, which leads to wilting, turgidity loss, and drying (Atkinson and Else, 2001; Shirai and Hagimori, 2004). The complete establishment of vascular connection takes $\approx 5$ to $8 \mathrm{~d}$, during which the scion is unable to uptake water through the rootstock, causing decreases in stomatal conductance and scion growth (Fernandez-Garcia et al., 2004; Johnson and Miles, 2011). Reducing transpiration for several days immediately after grafting can minimize water stress (Dabirian and Miles, 2017b; Rivard and Louws, 2006). Antitranspirant products that contain abscisic acid (ABA) can reduce transpiration by entering the leaf and inducing the stomatal closure under stress conditions by manipulating the ABA signaling pathway (Grill and Ziegler, 1998; Hetherington, 1998; Johnson, 2012; Nitzsche et al., 1991). Dabirian and Miles (2017b) reported that by using commercial antitranspirant products before grafting, the survival of the grafted watermelon transplants can be increased.

To advance the use of splice grafting, where both the cotyledons are removed from the rootstock, as an effective propagation strategy in watermelon production, more research is needed to increase the survival of newly grafted seedlings. Additionally, research is needed to assess survival in the field and to evaluate the impacts of this grafting method on fruit maturity and quality as compared with one-cotyledon grafted and nongrafted watermelon. Thus, the overall objectives of this study were to 1) test external applications of sucrose and antitranspirant solutions to rootstock seedlings before grafting to increase the survival of splicegrafted watermelon transplants where both cotyledons are removed from the rootstock; and 2) evaluate in-field survival of onecotyledon and splice-grafted watermelon and measure the effect of grafting on flowering time, harvest date, fruit yield and quality.

\section{Materials and Methods}

\section{Greenhouse studies}

Two experiments were carried out in 2018 at the Washington State University Northwestern Washington Research and Extension Center (WSU NWREC) greenhouse facilities in Mount Vernon, WA. Greenhouse temperature was set with an environmental control system (ARGUS Control Systems, Surrey, $\mathrm{BC}$, Canada) at $24 / 18^{\circ} \mathrm{C}$ for day/night. Inside the greenhouse, ambient sunlight was supplemented with $600-\mathrm{W}$ high-pressure sodium bulbs (PL Light Systems, Beamsville, ON, Canada) for $14 \mathrm{~h}$ (6:00 AM to 8:00 PM) in Expt. 1 and $12 \mathrm{~h}(6: 00$ AM to 6:00 PM) in Expt. 2. The difference in amount of time of supplemental lighting was due to different daylight duration as the experiments were conducted at different times of year. Four commercial antitranspirant products were applied to rootstock seedlings before grafting in the first experiment, and the two products resulting in the highest graft survival were applied in combination with a sucrose treatment before grafting in the second experiment. The design for both experiments was a randomized complete block with four replications and 18 plants per experimental unit. Expt. 1 had five treatments and was carried out twice, whereas Expt. 2 had four treatments and was carried out three times.

Plant material. Seedless watermelon cultivars were used for the scion in both experiments; 'Captivation' (Syngenta Seeds, Minneapolis, MN) was used in Expt. 1, and 'Secretariat' (Sakata Seeds America, Inc., Morgan Hill, CA) was used in Expt. 2. The scion cultivar was changed for Expt. 2 because 'Captivation' did not have uniform stem diameter, and germination rate was less than $90 \%$. Interspecific squash hybrid cultivar 'Super Shintosa' (C. maxima $\times C$. moschata/Calabacita Hyb) (Syngenta Seeds, Minneapolis, MN) was used as the rootstock for both experiments. For both experiments, scion and rootstock seeds were sown into 72 cell trays filled with potting mix (Sunshine \#3 N\&O; Sun Gro Horticulture, Agawam, MA), with rootstock seeded in every other row to allow for air circulation around the seedlings during graft healing. Planting dates were staggered for scion and rootstock so that seedlings had similar stem diameters (3.5$4.0 \mathrm{~mm})$ at time of grafting. For Expt. 1, 'Captivation' was sown on 22 Jan. and 20 Feb., whereas 'Super Shintosa' was sown on 4 Feb. and 4 Mar. for trials 1 and 2, respectively. For Expt. 2, 'Secretariat' was sown on 12 July, 14 Aug., and 24 Aug., whereas 'Super Shintosa' was seeded on 20 July, 23 Aug., and 4 Sept. for trials 1, 2, and 3, respectively.

Treatment application. In Expt. 1, the five treatments consisted of 1) antitranspirant A ( $2 \%$ solution; Root-Drench; Conservewater, Clackamas, OR), 2) antitranspirant B (4\% solution; Glycerin; Deepthi Organics, Greensboro, NC), 3 ) antitranspirant C $(0.08 \%$ solution; Beyond All Natural Plant Amendment; AgriHouse Brand Ltd., Berthoud, CO), 4) antitranspirant D (10\% solution; Moisture-Loc; Conservewater, 
Clackamas, OR), and 5) tap water (control). The antitranspirant products selected for this experiment were all labeled for use on vegetable transplants. Antitranspirants A, B, and $\mathrm{C}$ are stomata-closing; they condition the plant to produce additional amounts of ABA that affects the guard cells around the stomata, which causes stomata to close. Antitranspirant B is a stomata-coating antitranspirant that is a physical barrier to reduce water loss.

To achieve maximum effect, antitranspirant treatments were applied between 8:00 and 9:30 AM when temperature was near a daily low and humidity was near a daily high and before the photosynthesis process activated for the day (Aldasoro et al., 2019; Del Amor et al., 2010). Antitranspirant products were applied according to their label rate to rootstock seedlings $1 \mathrm{~d}$ before grafting. Antitranspirants $\mathrm{A}, \mathrm{B}$, and $\mathrm{C}$ were applied as a drench to rootstock seedlings in a single application of $30 \mathrm{~mL}$. Antitranspirant D (3 $\mathrm{mL}$ per seedling) was applied as a foliar spray to both sides of the leaves of rootstock seedlings. For the water control, $30 \mathrm{~mL}$ of water was applied as a drench to each scion and rootstock seedling. In Expt. 2, treatments were 1) sucrose ( $2 \%$ solution; IB37160 Sucrose; IBI Scientific, Peosta, IA), 2) sucrose + antitranspirant $A, 3$ ) sucrose + antitranspirant $\mathrm{B}$, and 4) tap water (control). Antitranspirants $A$ and $B$ were selected based on results from Expt. 1, and the sucrose treatment applied in this study was based on the study conducted by Dabirian and Miles (2017a). All treatments were applied as a drench to rootstock seedlings. The sucrose treatment was split into three applications, applied every other day starting $6 \mathrm{~d}$ before grafting, with $20 \mathrm{~mL}$ in the first and second applications, and 10 $\mathrm{mL}$ in the third application, which was $2 \mathrm{~d}$ before grafting. Both antitranspirant treatments were applied at $20 \mathrm{~mL}$ in combination with the third application of sucrose. The control consisted of $20 \mathrm{~mL}$ of tap water for the first and second application and $30 \mathrm{~mL}$ for the third application. Seedlings were watered following common greenhouse practices on days when treatments were not applied.

Grafting methods and healing. In Expt. 1, splice grafting occurred on $10 \mathrm{Feb}$. and 11 Mar. for trials 1 and 2, respectively. For Expt. 2, splice grafting occurred on 27 July, 31 Aug., and 10 Sept. for trials 1, 2, and 3, respectively. Both rootstock and scion seedlings were cut at a $60^{\circ}$ angle below the two cotyledons (Fig. 2). Rootstock seedlings were cut $0.5 \mathrm{~cm}$ below the cotyledons, whereas the scion was cut about $2 \mathrm{~cm}$ below the cotyledons to match stem diameters. The two cut stem surfaces were placed together and a watermelon grafting clip (3 mm; Johnny's Selected Seeds, Fairfield, ME) held the graft union together.

Immediately after grafting, plants were placed in a healing chamber within a greenhouse, and healed following a $9 \mathrm{~d}$ sitespecific protocol, which is summarized in Miles et al. (2016). The healing chamber was covered with one layer of clear plastic (0.15 mm polythene; Ginegar Plastic Products, Ginegar, Israel), and a thin film of water was added to the floor of the chamber to attain $100 \%$ relative humidity $(\mathrm{RH})$ inside the chamber when it was closed. The chamber was covered with a secondary layer of black fabric (Contractor Landscape Fabric; American Nettings \& Fabric, Ferndale, WA) to limit light penetration to the plants. For 1 and 2 DAG, plants were sealed in the chamber to maintain complete darkness. On 3 DAG, the chamber was opened (the plastic and fabric were lifted up from one long side of the chamber) for $5 \mathrm{~min}$ and water was added to the chamber. On 4 DAG, the chamber was opened for $15 \mathrm{~min}$ and the light level was increased by folding the black fabric half- way up the front side of the chamber. On 5 and 6 DAG, the chamber was opened for $45 \mathrm{~min}$ and $1.5 \mathrm{~h}$, respectively, water was added to the floor of the chamber and the black fabric was folded up from all the sides of the chamber such that only the top remained covered with the black fabric. On 7 and 8 DAG, the chamber was opened for 4 and $6 \mathrm{~h}$, respectively, and water was added to the floor of the chamber, with the top of the chamber remaining covered with the black fabric. From 9 DAG onwards, the chamber was left completely open day and night and the top of the chamber remained covered by the black fabric to decrease the light level on the plants. On 12 DAG, plants were removed from the chamber, placed on the greenhouse bench, and watered slowly as needed following common greenhouse practice.

\section{Field experimental location and design}

A field test of the most successful treatment from Expt. 2 was conducted at the Oregon State University (OSU) Hermiston Agricultural Research and Extension Center (HAREC) in Hermiston, OR (lat. $45^{\circ} 48^{\prime} 60.0^{\prime \prime} \mathrm{N}$, long. $119^{\circ} 17^{\prime} 27.7^{\prime \prime} \mathrm{W}$ ) in 2019. The Hermiston area is the center of watermelon production for the Pacific Northwest, where almost 800 ha of watermelon are produced. The experimental field has a soil type classified as Atkins Sandy Loam (mesic Fluvaquentic Endoaquepts). The experimental design was a randomized complete block with six replications of five treatments, with five plants per plot. Treatments were seedless watermelon cv. Secretariat nongrafted (control treatment) and grafted onto two commercial interspecific hybrid squash rootstock cvs. Tetsukabuto and Shintosa Camelforce, with two grafting methods, the splice method where both the cotyledons are removed from the rootstock, and the one-cotyledon method where one cotyledon is left on the rootstock.
A

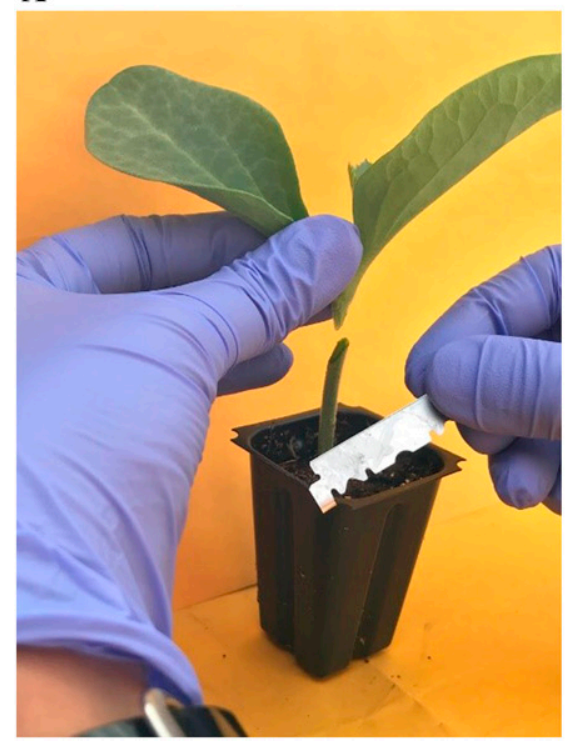

B

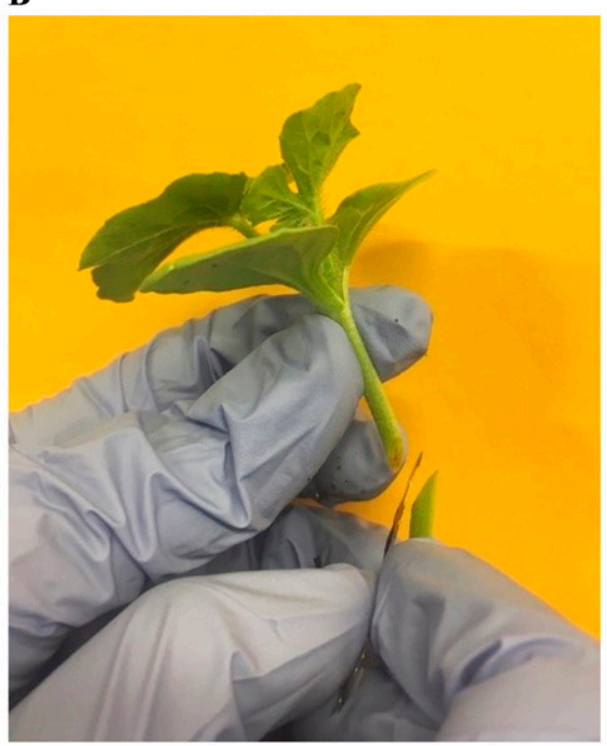

C

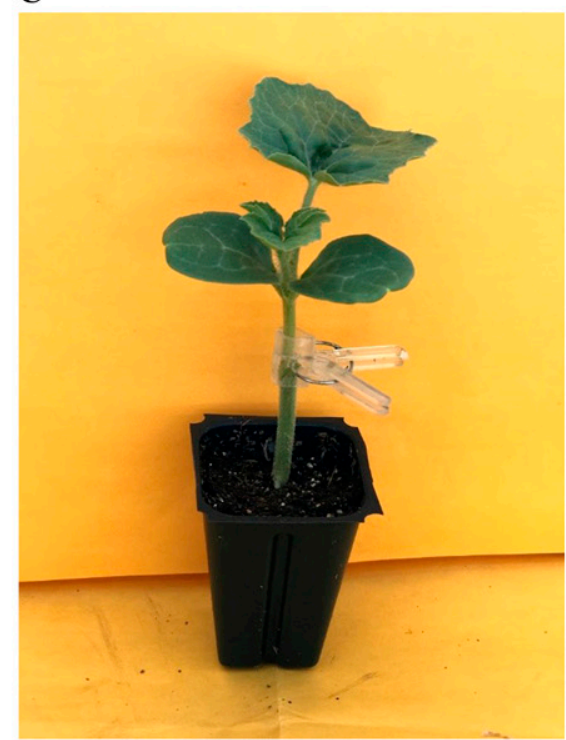

Fig. 2. Cutting watermelon rootstock (A) and scion (B) below the cotyledons, and joining of two cut surfaces with a grafting clip (C) in splice grafting. 
'Tetsukabuto' and 'Shintosa Camelforce' were selected for this study as they are both commonly used rootstocks for watermelon grafting (Camacho et al., 2011; Mohamed et al., 2014; Ricárdez-Salinas et al., 2010).

Plant material and grafting method. The nongrafted pollenizer 'Wild Card Plus' was seeded on 3 May in the greenhouse at OSU HAREC. Seeding of watermelon scion and rootstock, grafting, and healing were carried out in the greenhouse at WSU NWREC. All seeding was done in 72-cell trays (Sunshine \#3 N \& O; Sun Gro Horticulture, Agawam, MA). 'Secretariat' was sown on 19 Apr. and 'Shintosa Camelforce' and 'Tetsukubato' were sown on 29 Apr. The seeding dates were staggered so that all of the cultivars reached the appropriate size for grafting (fully developed first true-leaf stage for scion and early first true leaf stage for rootstock) at about the same time. For the splice grafting method, rootstock seedlings were treated with sucrose ( $2 \%$ solution) and antitranspirant A ( $2 \%$ solution) as a drench before grafting based on the results from Expt. 2 . Sucrose application was split into three applications, applied every other day starting $6 \mathrm{~d}$ before grafting: $20 \mathrm{~mL}$ for the first and second application, and $10 \mathrm{~mL}$ for the third application, which was $2 \mathrm{~d}$ before grafting. Antitranspirant A was applied at $20 \mathrm{~mL}$ in combination with the third application of sucrose. The splice grafting method was the same as described above, and the onecotyledon method is described by Hassell et al. (2008) and Miles et al. (2017). Grafting for both treatments was carried out on 7 May, at 7:30 AM to 11:00 AM to avoid water stress.

Immediately after grafting, plants were placed in healing chambers in the greenhouse for $9 \mathrm{~d}$ following the same healing protocol described for the greenhouse studies. Grafted plants were supported with a plastic straw during the healing process inside the healing chamber. After healing, the plants were moved to a greenhouse bench for $5 \mathrm{~d}$ and then transported to OSU HAREC on 28 May. At OSU HAREC, the grafted and nongrafted plants were maintained in the greenhouse from 28 May until 5 June. Mean greenhouse day (7:00 AM-7:00 PM) and night (7:00 $\mathrm{PM}-$ 7:00 Am) temperature and $\mathrm{RH}$ were $27.5^{\circ} \mathrm{C}$ and $18.5^{\circ} \mathrm{C}$, and $81 \%$ and $54 \%$, respectively. To acclimate (harden off) plants, they were exposed to outdoor conditions for $2 \mathrm{~h}$ each day from 2 to 5 June. Seedlings were watered as needed by providing water directly to the soil media without wetting the plant graft union. Before transplanting, the plastic straws were replaced with wooden stakes to eliminate plastic waste in the field.

Field preparation. The experimental field was prepared by rototilling $1.2-\mathrm{m}$ planting beds on $3-\mathrm{m}$ row centers on 7 May. At the time of soil rototilling, custom blended granular fertilizer $(89 \mathrm{~N}-89 \mathrm{P}-143 \mathrm{~K}-36 \mathrm{~S}-3.6 \mathrm{Cu}-$ $2.7 \mathrm{Zn}-1.3 \mathrm{~B} \mathrm{~kg} \cdot \mathrm{ha}^{-1}$ ) was broadcast applied in bands over the planting bed and incorporated to a depth of $20 \mathrm{~cm}$. Immediately after the beds were fertilized and formed, drip irrigation (DI) lines [20-cm emitter spacing,
$0.013 \mathrm{~m}^{3} \cdot \mathrm{h}^{-1}$ per $100 \mathrm{~m}$ at $69 \mathrm{kPa}$ (Aquatraxx; Toro Micro-Irrigation, El Cajon, CA)] were installed at a depth of $5 \mathrm{~cm}$, and the beds were covered with 1.2-m-wide and 25.4- $\mu$ m-thick black polyethylene plastic mulch (Climagro; Leco Industries, Inc., Quebec, Canada). Plants were transplanted into the experimental field on 5 June. Treatments were planted in a single row in the center of the planting bed with $0.9 \mathrm{~m}$ in-row spacing, with pollinizer plants placed on the side of the planting bed after every third treatment plant.

Field management. DI volume was provided to replace evapotranspiration $(\mathrm{Et})$ losses and was adjusted on a weekly basis to match seasonal demand by multiplying estimated Et with a watermelon crop coefficient $(\mathrm{Kc})$, produced by the OSU onsite weather station (Agrimet, Pacific Northwest Region, 2019). Average monthly irrigation applied was 127, 190, and $178 \mathrm{~mm}$ for June, July, and August, respectively. In-season fertilization was initiated 2 weeks after transplanting and was injected through the DI system every 2 weeks using $37.5 \%$ liquid urea ammonium nitrate (UAN) (32N-0P-0K) (J.R. Simplot Company, Boise, ID), $37.5 \%$ liquid $3 \mathrm{~N}-$ 7.8P-14.9K (Nachurs, Marion, $\mathrm{OH}$ ), 12.5\% Thio-Sul (Tessenderlo Kerley, Inc., Phoenix, $\mathrm{AZ}$ ), and $12.5 \%$ water at a total volume of 2.5 $\mathrm{L}$ to deliver a rate of $11.2 \mathrm{~kg} \cdot \mathrm{ha}^{-1} \mathrm{~N}$ per application. Throughout the trial, four fertilizer injections were applied from 5 June to 31 July, totaling $45 \mathrm{~kg} \cdot \mathrm{ha}^{-1}$ of in-season applied $\mathrm{N}$. Weeds were controlled in the betweenrow space with a spot herbicide treatment (1.5\% of glyphosate, RoundUp WeatherMax; Monsanto, St. Louis, MO) applied with a shielded backpack sprayer before the watermelon plants produced vines; later in the season, weeds were manually removed.

\section{Data collection}

Grafting survival. Survival in the two greenhouse experiments was assessed visually for the grafted plants on $4,9,16$, and 21 DAG. Grafted plants were counted as "survived" if scion leaves and rootstock stems were turgid, whereas severely wilted scion leaves and stems of both scion and rootstock were considered as graft failure.

Environmental conditions. In the greenhouse studies, temperature, RH (\%), and light intensity were monitored with data loggers (Hobo Onset, Bourne, MA) in the healing chamber and on the bench in the greenhouse next to the healing chamber (where plants were placed when they were taken out of the chamber) throughout all trials of both experiments, with data recorded every $15 \mathrm{~min}$. Throughout the field experiment, meteorological data were collected $300 \mathrm{~m}$ from the field site using a Pacific Northwest Agrimet weather station (AgriMet, Pacific Northwest Region, 2019). Soil temperature data were measured hourly with six sensors (HydroProbe Stevens Water, Portland, OR) placed at $20-\mathrm{cm}$ depth beneath the plastic mulch in the center of the bed of one border row.

In-field plant survival and vigor. Watermelon survival and establishment were eval- uated six times throughout the field season, on 13 June (8 DAT), 25 June (20 DAT), 1 July (26 DAT), 10 July (35 DAT), 19 July (44 DAT), and 29 July (54 DAT). At each date, plots were evaluated for plant survival (number of plants expressed as a percent), plant vigor $(1-10$ scale where $1=$ weak and $10=$ strong), and plant growth. Plant growth was assessed by counting the number of vines and measuring the length $(\mathrm{cm})$ of the main vine on one representative plant in each plot.

Flowering and harvest date. The emergence of the first male and female flowers were monitored daily in the morning between 9:00 $\mathrm{AM}$ and 11:00 $\mathrm{AM}$ for the center four plants in each plot in the field experiment. The emergence dates were recorded when the first male and female flowers were fully open. In each plot, fruit were tagged with the date when both the leaflet and tendril attached to the fruit pedicel were completely dry (fruit considered to be physiologically mature) (Georgia Vegetable Team, 2000).

Fruit yield and quality. Three fruit per plot were harvested at each time, 0,7 , and $14 \mathrm{~d}$ after fruit physiological maturity, to assess fruit weight and internal ripeness characteristics (fruit quality) relative to the presence of external indicators of fruit maturity (brown leaflet and tendril at fruit pedicel) commonly used to harvest nongrafted fruit. Fruit weight at each of the three harvest dates was recorded for each plot. After the 14-d harvest, the remaining fruit were harvested per plot, and their weight was summed with all other harvest dates to calculate total yield. On each harvest date, the three harvested fruit per plot were assessed for fruit quality. Each fruit was weighed then cut in half longitudinally, and each half was rated for hollow heart based on a scale of 0 to 5 , where $0=$ no visible cracking; $1=<6 \mathrm{~mm}$ cracking in one direction, marketable; $2=6$ to $13 \mathrm{~mm}$ cracking in a single or multiple directions, marketable; $3=13$ to $25 \mathrm{~mm}$ cracking in one or multiple directions, not marketable; $4=25$ to $38 \mathrm{~mm}$ cracking in multiple directions, not marketable; and $5=>38 \mathrm{~mm}$ cracking with center cavity of fruit exposed, not marketable. Each half was then quartered, and the number of black hard seed were counted for the exposed fruit surfaces of all four quarters for each fruit. From one representative quarter, flesh firmness, total soluble solids (TSS), and lycopene content were measured. Flesh firmness (reported as Newton, N) was measured $3 \mathrm{~cm}$ below the centermost portion of the quarter to a depth of $1 \mathrm{~cm}$ with a penetrometer (Fruit Hardness Tester; Lutron Electronic Enterprise Co., Taipei, Taiwan) fixed with a $6-\mathrm{mm}$ cylindrical blunt-end tip. From the same quarter, TSS $\left(\%\right.$, measured as $\left.{ }^{\circ} \mathrm{Brix}\right)$ of the juice was measured from the centermost portion of the quadrant using an analog refractometer (Atago USA Inc., Tokyo, Japan).

For lycopene analysis, $50 \mathrm{~cm}^{3}$ was removed from the center of the fruit quarter and frozen at $-80{ }^{\circ} \mathrm{C}$ until all samples were collected. Samples were transported in a vacuum insulated cooler with dry ice to 
WSU NWREC on 4 Nov. and placed in a freezer at $-20{ }^{\circ} \mathrm{C}$ until 25 Nov. Lycopene content $\left(\mu \mathrm{g} \cdot \mathrm{g}^{-1}\right)$ was determined using the spectrophotometer protocol based on Dabirian et al. (2017). Samples were removed from the freezer and kept at room temperature $\left(23{ }^{\circ} \mathrm{C}\right)$ for $10 \mathrm{~min}$, then each sample was homogenized in a blender (Magic Bullet; Homeland Housewares, Pacoima, CA). Three 1-g subsamples were taken from each homogenized sample and placed in separate plastic centrifuge tubes wrapped in aluminum foil. Sixteen milliliters of a high-performance liquid chromatography grade 2:3 acetone:hexane solution was added to each tube. The tubes were agitated by hand for $1 \mathrm{~min}$ for thorough mixing, then returned back to the freezer at $-20^{\circ} \mathrm{C}$ for 1.5 $\mathrm{h}$. Tubes were removed from the freezer and left to rest for $5 \mathrm{~min}$ to separate the hexane and dissolved lycopene from the rest of the mixture. The hexane portion of each subsample was transferred to a glass cuvette using a disposable pipette, and the cuvette was placed in a spectrophotometer (ultravioletVIS Spectrophotometer ultraviolet-1280; Shimadzu Scientific Instruments, Inc., Columbia, MD). Absorbance readings for each subsample were taken at $453,505,645$, and $663 \mathrm{~nm}$ wavelengths and total lycopene was calculated using the following formula:

Lycopene $\left(\mu \mathrm{g} \cdot \mathrm{g}^{-1}\right.$ fw sample)

$$
\begin{aligned}
= & {[(-0.0458 * A 663)+(0.204 * A 645)} \\
& +(0.372 * A 505)-(0.0806 * A 453)] \\
& *[10 /(0.1042)]
\end{aligned}
$$

\section{Data analyses}

All greenhouse and field data were analyzed using JMP software (Version 14.0.0 for Windows; SAS Institute, Cary, NC). Data for all parameters were tested for normality using Shapiro-Wilk test. The sucrose and antitranspirant treatments and water control were explanatory variables, whereas grafting survival at each DAG were response variables. Field data were analyzed through the fit model function as a one-way analysis of variance with a $P \leq 0.05$ level of significance. When significant effects were identified, means were separated using Tukey's highly significant difference test $(\alpha=0.05)$

\section{Results}

Grafted plant survival in the greenhouse. In Expt. 1, survival (\%) of splice-grafted watermelon plants differed due to antitranspirant treatment and days after grafting $(P<0.0001$ for both), but there was no difference due to trial. The survival of grafted plants was near $100 \%$ for all five treatments $4 \mathrm{DAG}(P=0.88)$; however, at $9 \mathrm{DAG}$, plant survival began to decline for all the treatments and was $65 \%$ on average $(P=$ 0.01) (Table 1). At $16 \mathrm{DAG}$, survival of plants treated with water declined to $20 \%(P=0.0004)$ and further declined to $7 \%$ at 21 DAG $(P<$ $0.0001)$. In contrast, survival of plants treated with antitranspirants was $57 \%$ and $51 \%$ on average 16 and 21 DAG, respectively. Plants treated with antitranspirant $\mathrm{A}$ and $\mathrm{B}$ had the best survival for splice-grafted plants $(68 \%$ and $53 \%$, respectively) among the four antitranspirant treatments that were tested.

In Expt. 2, survival of splice-grafted watermelon differed due to treatment, trial and days after grafting $(P<0.0001$ for all $)$. Survival of splice-grafted watermelon was greatest for plants that received sucrose + antitranspirant $\mathrm{A}$ and sucrose + antitranspirant B ( $91 \%$ and $83 \%$, respectively), followed by plants that received only the sucrose solution $(67 \%)$, and was lowest for plants that received water $(25 \%)$. Survival of grafted plants that received sucrose with and without antitranspirant treatments was $67 \%$ to $87 \%$ on average in the three trials, whereas survival of plants that received water ranged from $40 \%$ in trial 1 to $15 \%$ to $19 \%$ in trials 2 and 3 (Table 2). At 4 DAG, plant survival was near $100 \%$ for all four treatments. However, plant survival declined thereafter and was $92 \%$ on average at 9 $\mathrm{DAG}, 77 \%$ on average at $16 \mathrm{DAG}$, and $66 \%$ on average at $21 \mathrm{DAG}$. At $16 \mathrm{DAG}$, survival of plants treated with water declined to $47 \%$ on average, and at $21 \mathrm{DAG}$ declined to $25 \%$ on average. In contrast, survival of plants treated with sucrose with or without antitranspirants was $87 \%$ and $80 \%$ on average 16 and $21 \mathrm{DAG}$, respectively.

Environmental conditions in the greenhouse. Daily average temperature and $\mathrm{RH}$ in the healing chamber and in the greenhouse were similar for both Expts. 1 and 2. Daily average temperature inside the healing chamber was 23 to $28{ }^{\circ} \mathrm{C}$, and the daily average temperature in the greenhouse was 21 to $27{ }^{\circ} \mathrm{C}$. During days 1 to 4 after grafting, when the healing chamber was closed and entirely covered with black fabric, the daily

Table 1. Survival (\%) of grafted watermelon transplants measured at 4, 9, 16, and $21 \mathrm{~d}$ after grafting (DAG) at Mount Vernon, WA. Before grafting, rootstock seedlings received applications of antitranspirant treatments, and grafting was carried out on 10 Feb. and 11 Mar. 2018 for trials 1 and 2, respectively.

\begin{tabular}{lcccc}
\hline & \multicolumn{4}{c}{ Survival \% } \\
\cline { 2 - 5 } Treatment $^{z}$ & 4 DAG & 9 DAG & 16 DAG & 21 DAG \\
\hline Antitranspirant A & 100 & $82 \mathrm{a}^{\mathrm{y}}$ & $71 \mathrm{a}$ & $68 \mathrm{a}$ \\
Antitranspirant B & 99 & $75 \mathrm{ab}$ & $60 \mathrm{ab}$ & $53 \mathrm{ab}$ \\
Antitranspirant C & 99 & $64 \mathrm{~b}$ & $55 \mathrm{bc}$ & $47 \mathrm{~b}$ \\
Antitranspirant D & 97 & $57 \mathrm{~b}$ & $40 \mathrm{bc}$ & $35 \mathrm{bc}$ \\
Water (control) & 97 & $45 \mathrm{~b}$ & $20 \mathrm{c}$ & $7 \mathrm{c}$ \\
$P$ value & 0.88 & 0.01 & 0.0004 & $<0.0001$ \\
\hline
\end{tabular}

${ }^{\mathrm{z}}$ Antitranspirant A (2\% solution; Root-Drench; Conservewater, Clackamas, OR), antitranspirant B (4\% solution; Glycerin; Deepthi Organics, Greensboro, NC), 3) antitranspirant C (0.08\% solution; Beyond All Natural Plant Amendment; AgriHouse Brand Ltd., Berthoud, CO), antitranspirant D (10\% solution; Moisture-Loc; Conservewater, Clackamas, OR). Scion is 'Captivation' and rootstock is 'Super Shintosa'. ${ }^{\mathrm{y}}$ Mean separation letters generated using least square means statement in JMP (version 14.0 for Windows; SAS Institute) at $P \leq 0.05$. Values followed by the same letter within a column are not significantly different.

Table 2. Survival (\%) of grafted watermelon transplants measured at 4, 9, 16, and $21 \mathrm{~d}$ after grafting (DAG) at Mount Vernon, WA. Before grafting, rootstock seedlings received applications of sucrose and

\begin{tabular}{|c|c|c|c|c|}
\hline \multirow[b]{3}{*}{ Treatment ${ }^{z}$} & \multicolumn{4}{|c|}{ Survival \% } \\
\hline & $4 \mathrm{DAG}$ & $9 \mathrm{DAG}$ & $16 \mathrm{DAG}$ & $21 \mathrm{DAG}$ \\
\hline & \multicolumn{4}{|c|}{ Trial 1} \\
\hline Sucrose & 100 & 97 & $74 b^{y}$ & $71 \mathrm{~b}$ \\
\hline Sucrose + antitranspirant $\mathrm{A}$ & 100 & 100 & $95 \mathrm{a}$ & $89 \mathrm{a}$ \\
\hline Sucrose + antitranspirant B & 100 & 100 & $90 \mathrm{a}$ & $84 \mathrm{ab}$ \\
\hline Water (control) & 98 & 80 & $62 \mathrm{~b}$ & $40 \mathrm{~b}$ \\
\hline \multirow[t]{2}{*}{$P$ value } & 0.72 & 0.33 & 0.04 & 0.005 \\
\hline & \multicolumn{4}{|c|}{ Trial 2} \\
\hline Sucrose & $98 \mathrm{a}$ & $95 \mathrm{a}$ & $82 \mathrm{a}$ & $68 \mathrm{~b}$ \\
\hline Sucrose + antitranspirant $\mathrm{A}$ & $98 \mathrm{a}$ & $97 \mathrm{a}$ & $94 \mathrm{a}$ & $90 \mathrm{a}$ \\
\hline Sucrose + antitranspirant B & $100 \mathrm{a}$ & $99 \mathrm{a}$ & $92 \mathrm{a}$ & $86 \mathrm{a}$ \\
\hline Water (control) & $90 \mathrm{~b}$ & $78 \mathrm{~b}$ & $58 \mathrm{~b}$ & $19 \mathrm{c}$ \\
\hline \multirow[t]{2}{*}{$P$ value } & 0.03 & 0.003 & 0.01 & 0.0002 \\
\hline & \multicolumn{4}{|c|}{ Trial 3} \\
\hline Sucrose & 100 & $97 \mathrm{a}$ & $70 \mathrm{~b}$ & $62 \mathrm{~b}$ \\
\hline Sucrose + antitranspirant $\mathrm{A}$ & 99 & $97 \mathrm{a}$ & $93 \mathrm{a}$ & $93 \mathrm{a}$ \\
\hline Sucrose + antitranspirant B & 100 & $99 \mathrm{a}$ & $94 \mathrm{a}$ & $80 \mathrm{a}$ \\
\hline Water (control) & 97 & $70 \mathrm{~b}$ & $20 \mathrm{c}$ & $15 \mathrm{c}$ \\
\hline$P$ value & 0.84 & 0.001 & $<0.0001$ & $<0.0001$ \\
\hline
\end{tabular}
antitranspirant treatments, and grafting was carried out for trials 1, 2, and 3 on 27 July, 31 Aug., and 10 Sept. 2018, respectively.

${ }^{\mathrm{z}}$ Sucrose (2\% solution; IB37160 Sucrose; IBI Scientific, Peosta, IA), antitranspirant A (2\% solution; RootDrench; Conservewater, Clackamas, OR), antitranspirant B (4\% solution; Glycerin; Deepthi Organics, Greensboro, NC). Scion is 'Secretariat' and rootstock is 'Super Shintosa'.

${ }^{\mathrm{y}}$ Mean separation letters generated using least square means statement in JMP (version 14.0 for Windows; SAS Institute) at $P \leq 0.05$. Values followed by the same letter within a column are not significantly different. 
Table 3. In-field watermelon plant survival (\%) and plant vigor of grafted and nongrafted 'Secretariat' at 35, 44, and $54 \mathrm{~d}$ after transplanting (DAT) at Hermiston, OR, in 2019.

\begin{tabular}{|c|c|c|c|c|c|c|}
\hline \multirow[b]{2}{*}{ Treatment $^{\mathrm{z}}$} & \multicolumn{2}{|c|}{35 DAT } & \multicolumn{2}{|c|}{44 DAT } & \multicolumn{2}{|c|}{54 DAT } \\
\hline & Survival (\%) & Vigor $(1-10)^{y}$ & Survival (\%) & Vigor $(1-10)$ & $\overline{\text { Survival }(\%)}$ & Vigor $(1-10)$ \\
\hline One-cotyledon, S/Tetsukabuto & $98 \mathrm{a}$ & 7.3 & $96 \mathrm{a}$ & $8.2 \mathrm{ab}$ & $95 \mathrm{a}$ & $7.3 \mathrm{a}$ \\
\hline Splice-grafted, S/Shintosa Camelforce & $100 \mathrm{a}$ & 7.7 & $97 \mathrm{a}$ & $8.8 \mathrm{a}$ & $98 \mathrm{a}$ & $7.5 \mathrm{a}$ \\
\hline Secretariat (nongrafted) & $88 \mathrm{~b}$ & 7.3 & $83 \mathrm{~b}$ & $7.0 \mathrm{~b}$ & $84 \mathrm{~b}$ & $5.8 \mathrm{~b}$ \\
\hline$P$ value & 0.0001 & 0.62 & 0.006 & 0.003 & 0.004 & 0.0002 \\
\hline
\end{tabular}

${ }^{\mathrm{z}}$ All grafted plants had scion cv. Secretariat $(\mathrm{S})$ and are denoted as scion/rootstock.

${ }^{\mathrm{y}}$ Plant vigor rating was on a $1-10$ scale where $1=$ weak and $10=$ strong.

${ }^{\mathrm{x}}$ Mean separation letters generated using least square means statement at $P \leq 0.05$. Values followed by the same letter within a column are not significantly different.

average temperature inside the chamber was the same as the temperature inside the greenhouse, 24 to $27^{\circ} \mathrm{C}$. Daily average $\mathrm{RH}$ during this time was $94 \%$ to $98 \%$ inside the chamber and $50 \%$ to $72 \%$ in the greenhouse, and the daily average light intensity in the chamber was $1.2 \mu \mathrm{mol} \cdot \mathrm{m}^{-2} \cdot \mathrm{s}^{-1}$, compared with 270 to $320 \mu \mathrm{mol} \cdot \mathrm{m}^{-2} \cdot \mathrm{s}^{-1}$ in the greenhouse. From 5 to $6 \mathrm{DAG}$, when plants in the chamber were exposed to the greenhouse environment for $1.5 \mathrm{~h}$ or less each day, and the chamber was partially covered with black fabric, daily average temperature inside the chamber was 24 to $26^{\circ} \mathrm{C}$ in Expt. 1, and 25 to $28^{\circ} \mathrm{C}$ in Expt. 2. Temperature in the greenhouse was 23 to $25{ }^{\circ} \mathrm{C}$ in Expt. 1 and 24 to $27^{\circ} \mathrm{C}$ in Expt. 2. Daily average RH during this time was $94 \%$ to $96 \%$ inside the chamber and $30 \%$ to $50 \%$ in the greenhouse in both experiments. The daily average light intensity in the chamber was 6.0 to 6.8 $\mu \mathrm{mol} \cdot \mathrm{m}^{-2} \cdot \mathrm{s}^{-1}$ in Expt. 1 and 7.2 to 8.8 $\mu \mathrm{mol} \cdot \mathrm{m}^{-2} \cdot \mathrm{s}^{-1}$ in Expt. 2, whereas the light intensity in the greenhouse was 240 to 330 $\mu \mathrm{mol} \cdot \mathrm{m}^{-2} \cdot \mathrm{s}^{-1}$ during the two experiments. For 7 to 9 DAG, when plants in the chamber were exposed $5 \mathrm{~h}$ on average each day to the greenhouse environment, the temperature inside the chamber and the temperature in the greenhouse was 23 to $25^{\circ} \mathrm{C}$ in Expt. 1 and 24 to $27^{\circ} \mathrm{C}$ in Expt. 2. Daily average RH during this time was $78 \%$ to $98 \%$ inside the chamber and $34 \%$ to $52 \%$ in the greenhouse. The daily average light intensity in the chamber was 142 to $150 \mu \mathrm{mol} \cdot \mathrm{m}^{-2} \cdot \mathrm{s}^{-1}$ in Expt. 1 and 170 to $185 \mu \mathrm{mol} \cdot \mathrm{m}^{-2} \cdot \mathrm{s}^{-1}$ in Expt. 2 , and the light intensity in the greenhouse was 334 to $364 \mu \mathrm{mol} \cdot \mathrm{m}^{-2} \cdot \mathrm{s}^{-1}$ during the two experiments. For 10 to $21 \mathrm{DAG}$, when the plants were on the greenhouse bench, the daily average temperature in the greenhouse was 24 and $26^{\circ} \mathrm{C}$ in Expts. 1 and 2, respectively, and the RH was $62 \%$ to $67 \%$ for the two experiments. The daily average light intensity in the greenhouse was 220 to 330 $\mu \mathrm{mol} \cdot \mathrm{m}^{-2} \cdot \mathrm{s}^{-1}$ in Expt. 1 and 320 to 370 $\mu \mathrm{mol} \cdot \mathrm{m}^{-2} \cdot \mathrm{s}^{-1}$ in Expt. 2.

Environmental conditions in the field. Daily mean, minimum, and maximum air temperatures during the 3-month field growing season (June-August) were 24, 14.5, and $30{ }^{\circ} \mathrm{C}$, respectively. Mean $\mathrm{RH}$ was $46 \%$, and average wind velocity was $2.8 \mathrm{~m} \cdot \mathrm{s}^{-1}$ at a $207^{\circ}$-azimuth bearing, measured at a height of $3 \mathrm{~m}$. Average monthly soil temperature

Table 4. Days after transplanting (DAT) for appearance of first male and female flowers, total fruit yield (kilograms) per plot, mean watermelon flesh firmness (Newton, N) of grafted and nongrafted 'Secretariat' in Hermiston, OR, in 2019.

\begin{tabular}{lccc}
\hline Treatment $^{z}$ & First flowering (DAT) & Yield $^{\mathrm{y}}(\mathrm{kg})$ & Fruit firmness (N) \\
\hline One-cotyledon, S/Shintosa Camelforce & $35 \mathrm{~b}^{\mathrm{x}}$ & 49.0 & $6.8 \mathrm{~b}$ \\
One-cotyledon, S/Tetsukabuto & $36 \mathrm{~b}$ & 55.1 & $7.0 \mathrm{ab}$ \\
Splice-grafted, S/Shintosa Camelforce & $37 \mathrm{a}$ & 53.9 & $8.2 \mathrm{a}$ \\
Splice-grafted, S/Tetsukabuto & $37 \mathrm{a}$ & 54.0 & $7.0 \mathrm{ab}$ \\
Secretariat & $35 \mathrm{~b}$ & 54.3 & $5.3 \mathrm{c}$ \\
$P$ value & $<0.0001$ & 0.536 & $<0.0001$ \\
\hline
\end{tabular}

${ }^{\mathrm{z}}$ All grafted plants had scion cv. Secretariat (S) and are denoted as scion/rootstock.

${ }^{\mathrm{y}}$ Three fruit were harvested at three harvest dates $(0,7$, and $14 \mathrm{~d})$ after fruit physiological maturity, when both the leaflet and tendril attached to the fruit pedicel. After the 14-d harvest, the remaining fruit were harvested per plot, and their weight was summed with all other harvest days to calculate total yield.

${ }^{x}$ Mean separation letters generated using least square means statement at $P \leq 0.05$. Values followed by the same letter within a column are not significantly different.

at a depth of $20 \mathrm{~cm}$ for the 3-month summer growing season was $24.9,25.5$, and $25.4{ }^{\circ} \mathrm{C}$, respectively.

In-field plant survival and vigor. Survival of watermelon plants in the field did not differ due to grafting treatment over the first three rating periods and was $100 \%$ on average at 8 DAT $(P=0.42), 99 \%$ on average at 20 DAT $(P=0.07)$, and $98 \%$ on average at 26 DAT $(P=0.16)$ (data not shown). Plant survival of the nongrafted control declined to $88 \%$ at 35 DAT $(P<0.0001)$ and $84 \%$ at 54 DAT $(P<$ $0.004)$, whereas all of the grafted treatments were $99 \%$ on average at 35 DAT and $96 \%$ on average at both 44 DAT and 54 DAT (Table 3). Watermelon plant vigor also did not differ among grafted and nongrafted treatments for the first rating periods, and was 7.2 on 8 DAT $(P=0.27), 5.4$ on 20 DAT $(P=0.24), 6.1$ on $26 \mathrm{DAT}(P=0.84)$, and 7.6 on $35 \mathrm{DAT}(P=0.62)$ (not all data shown). At 44 DAT, both splice-grafted treatments were more vigorous ( 8.8 on average) than the nongrafted control (7.0), and the onecotyledon grafted treatments had intermediate vigor $(8.0$ on average $)(P<0.003)$ (Table 3$)$. At the final measurement date (54 DAT), all grafted treatments were more vigorous (7.7 rating on average) than the nongrafted control (5.8 rating) $(P<0.0002)$. At all six rating periods that spanned the growing season, number of vines and vine length did not differ among grafted treatments and the nongrafted control (data not shown). At the last rating at $54 \mathrm{DAT}$, average number of vines for all grafted treatments was seven compared with six vines for the nongrafted control $(P=0.64)$. Average vine length at 54 DAT was $83 \mathrm{~cm}$ for all the grafted treatments, and $86 \mathrm{~cm}$ for the nongrafted control $(P=0.81)$.

Flowering and harvest dates. The time of emergence for the first male and female flowers was the same within treatments and was 35 DAT on average $(P=0.87)$ (data not shown). Flowering was delayed by an average of $2 \mathrm{~d}$ for splice-grafted watermelon (37 DAT on average) compared with onecotyledon grafted plants and the nongrafted control (35 DAT on average) $(P<0.0001)$ (Table 4). First harvest was when fruit reached physiological maturity (both the leaflet and tendril attached to the fruit pedicel were completely dry), on 13 Aug. (70 DAT) for all the treatments. Second harvest was on 20 Aug. (77 DAT), and third harvest was on 27 Aug. (84 DAT).

Fruit yield and quality. There was no difference in total yield between nongrafted and grafted treatments $(P=0.50)$ (Table 4). The average total yield over all three harvest dates was $53.3 \mathrm{~kg}$ per plot, and ranged from $49.0 \mathrm{~kg}$ (one-cotyledon grafted onto 'Shintosa Camelforce') to $55.1 \mathrm{~kg}$ (one-cotyledon grafted onto 'Tetsukabuto'). There was a difference in individual fruit weight over the three harvest periods $(P<0.0001)$, with the heaviest watermelons $(7.6 \mathrm{~kg})$ harvested at $14 \mathrm{~d}$, compared with $0 \mathrm{~d}$ and $7 \mathrm{~d}$ (6.0 and $6.7 \mathrm{~kg}$, respectively) (Table 5). However, individual watermelon fruit weight was unaffected by grafting treatment $(P=0.20)$, and there was no interaction between grafting treatment and harvest date $(P=0.90)$. The occurrence of hollow heart formation was very low on all harvest dates $(0.7 \mathrm{~mm}$ 
Table 5. Fruit weight ( $\mathrm{kg} /$ fruit), hollow heart rating, hard seed count, fruit firmness (Newton, N), total soluble solids (TSS, $\%)$, and lycopene ( $\mu$ g. $\mathrm{g}^{-1}$ ) at three harvest dates $(0,7$, and $14 \mathrm{~d})$ after fruit physiological maturity, when both the leaflet and tendril attached to the fruit pedicel were completely dry, in Hermiston, $\mathrm{OR}$, in 2019 .

\begin{tabular}{|c|c|c|c|c|c|c|}
\hline Harvest & Wt (kg/fruit) & Hollow heart $(1-5)^{\mathrm{z}}$ & Hard seed & Fruit firmness $(\mathrm{N})$ & TSS (\%) & Lycopene $\left(\mu \mathrm{g} \cdot \mathrm{g}^{-1}\right)$ \\
\hline$\overline{0 d}$ & $6.1 \mathrm{~b}^{\mathrm{y}}$ & 0.6 & 5 & $7.2 \mathrm{a}$ & $10.67 \mathrm{~b}$ & $16.74 \mathrm{~b}$ \\
\hline $7 \mathrm{~d}$ & $6.7 \mathrm{~b}$ & 0.8 & 4 & $7.2 \mathrm{a}$ & $10.38 \mathrm{~b}$ & $31.38 \mathrm{a}$ \\
\hline $14 \mathrm{~d}$ & $7.6 \mathrm{a}$ & 0.7 & 6 & $6.2 \mathrm{~b}$ & $11.20 \mathrm{a}$ & $25.80 \mathrm{a}$ \\
\hline$P$ value & $<0.001$ & 0.70 & 0.37 & 0.0051 & 0.0012 & 0.0002 \\
\hline
\end{tabular}

${ }^{\mathrm{z}}$ Hollow heart rating on $0-5$ scale, where $0=$ no visible cracking; $1=<6 \mathrm{~mm}$ cracking in one direction, marketable; $2=6-13 \mathrm{~mm}$ cracking in a single or multiple directions, marketable; $3=13-25 \mathrm{~mm}$ cracking in one or multiple directions, not marketable; $4=25-38 \mathrm{~mm}$ cracking in multiple directions, not marketable; and $5=>38 \mathrm{~mm}$ cracking with center cavity of fruit exposed, not marketable.

${ }^{\mathrm{y}}$ Mean separation letters generated using least square means statement at $P \leq 0.05$. Values followed by the same letter within a column are not significantly different.

cracking on average) $(P=0.70)$ (Table 5). There was also no difference in the occurrence of hollow heart formation due to grafting treatment $(P=0.15)$, nor was there an interaction between grafting treatment and harvest dates $(P=0.73)$. Similarly, there was no difference in the number of hard seeds due to harvest date $(P=0.36)$ or grafting treatment $(P=0.88)$. The average number of hard seeds for all the grafting treatments was 5 at 0 $\mathrm{d}, 4$ at $7 \mathrm{~d}$ and 6 at $14 \mathrm{~d}(P=0.36)$ (Table 5). Watermelon fruit firmness differed due to both harvest date $(P=0.005)$ and grafting treatment $(P<0.0001)$; however, there was no interaction between harvest date and grafting treatment $(P=0.30)$. Fruit firmness was lowest for all the treatments harvested at $14 \mathrm{~d}(6.2 \mathrm{~N}$ on average) compared with fruit harvested at both $0 \mathrm{~d}$ and $7 \mathrm{~d}(7.2 \mathrm{~N}$ on average) (Table 5). Splice-grafted watermelon on 'Shintosa Camelforce' rootstock had the firmest flesh $(8.2 \mathrm{~N})$, nongrafted watermelon had the lowest firmness $(5.3 \mathrm{~N})$, and the other treatments were intermediate (6.9 $\mathrm{N}$ on average) (Table 4). TSS was similar at 0 and $7 \mathrm{~d}(10.55 \%$ on average $)$ but increased at the $14 \mathrm{~d}$ harvest $(11.9 \%)(P=$ 0.001 ) (Table 5). However, there was no difference in TSS between grafted treatments and the nongrafted control $(P=0.32)$. Lycopene content differed over harvest date and was greatest at $7 \mathrm{~d}\left(31.38 \mu \mathrm{g} \cdot \mathrm{g}^{-1}\right)$ compared with $0 \mathrm{~d}\left(16.74 \mu \mathrm{g} \cdot \mathrm{g}^{-1}\right)$ and $14 \mathrm{~d}\left(25.80 \mu \mathrm{g} \cdot \mathrm{g}^{-1}\right)$ $(P=0.0002)$ (Table 5). However, lycopene content in watermelon was unaffected by grafting treatment $(P=0.27)$.

\section{Discussion and Conclusions}

The overall objectives of this study were to increase survival of splice-grafted watermelon transplants and assess their productivity in a field setting. Results from the greenhouse experiments indicate that a drench application of sucrose solution in combination with a commercial antitranspirant to rootstock seedlings before grafting can significantly increase grafting success when both cotyledons are removed from the rootstock before grafting. In this study, antitranspirant products that condition plants to produce ABA, which causes guard cells around stomata to close, resulted in greater grafting success than a stomata-coating antitranspirant product. This result is similar to findings in two other studies where survival of grafted watermelon increased when sucrose solution and antitranspirant were applied to rootstock seedlings before grafting (Dabirian and Miles, 2017a, 2017b). Sucrose may improve callus formation and connectivity of vascular bundles at the graft interface (Hunter et al., 2004; Ogata et al., 2005). When the vascular tissue is severed and the two seedlings are joined together through grafting, the rootstock has few carbohydrate reserves in the stem, and although the scion has stored carbohydrates in the cotyledons and the leaves, these are not able to reach the rootstock until cellular and vascular connections are restored (Melnyk, 2017). Removing both cotyledons from the rootstock slows the rate of callus formation and reduces watermelon grafting success, suggesting a correlation between carbohydrate status in the stem and seedling survival in grafted watermelon (Dabirian and Miles, 2017a). Applying sucrose in combination with an antitranspirant product before grafting appeared to better prepare seedlings for the stress of grafting and healing, leading to greater graft survival. In this study, we were unable to precisely control the temperature and other environmental factors in the greenhouse due to the age and limitations of the facility. More research is needed to determine whether specific temperature, $\mathrm{RH}$, and light factors increase grafting survival.

Survival and vigor ratings of all watermelon plants once transplanted into the field were similar during the initial establishment period. In the mid to late season, as temperature-induced water demand increased and fruiting load stress was occurring, all grafted watermelon plants performed better than the nongrafted plants. The improved growth of grafted compared with nongrafted plants suggests these rootstocks may increase water and nutrient uptake when there is no biotic or abiotic stress (Davis et al., 2008; Food and Agriculture Organization of the United Nations, 2012; King et al., 2008), but more importantly illustrates the comparable performance of time- and laborefficient splice-grafted watermelon to the traditional labor-intensive one-cotyledon method. To date, the authors are not aware of any published study that has evaluated splice-grafted watermelon in a field production setting. It is important to note that naming convention of grafting methods vary in published literature, which sometimes refers to the one-cotyledon grafting method as splice-grafting (Guan 2019; Lee and Oda, 2010; Yetisir and Karaca, 2018). The splicegrafted method as performed in this study removed both the cotyledons from the rootstock (Dabirian and Miles, 2017a; Devi and Miles, 2018, 2020). Vine number and length of splice-grafted, one-cotyledon grafted, and nongrafted watermelon plants did not differ, indicating the comparative growth of splicegrafted plants in a production system setting. Although first flowering was delayed $2 \mathrm{~d}$ for splice-grafted plants, indicators of fruit physiological maturity occurred at the same time as other treatments.

Fruit quality parameters are important for assessing market acceptability of grafted watermelon because the success of grafting comes with the challenge to produce highquality fruit that is equal to or better than nongrafted watermelon (Bruton et al., 2009; Colla et al., 2010; Proietti et al., 2008). Changes in fruit quality as a consequence of grafting can affect the external appearance and/or flesh characteristics of the fruit (Davis and Perkins-Veazie, 2005; Davis et al., 2008; Fredes et al., 2017; Kyriacou et al., 2017; Rouphael et al., 2010; Yetisir et al., 2003). In watermelon, two primary quality-related characteristics are fruit weight and flesh properties (Fredes et al., 2017). Results from the current study indicate that the grafting process itself does not alter fruit size or essential fruit quality attributes (e.g., hollow heart formation, hard seeds, TSS and lycopene content) of splice-grafted watermelon plants. In the current study, flesh of splicegrafted watermelon fruit was firmer compared with nongrafted watermelon and slightly firmer than fruit from plants grafted with the one-cotyledon method. Similar results were found in previous studies that compared fruit firmness of one-cotyledon grafted watermelon to nongrafted fruit (Buller et al., 2013; Dabirian et al., 2017; Davis and Perkins-Veazie, 2005; Wimer et al., 2015; Yetisir et al., 2003). Increased fruit firmness is viewed as a positive enhancement of fruit quality as firmer flesh is preferred both by consumers and processors; firm fruit have an extended shelf life both for fresh market and for fresh-cut watermelon (Bruton et al., 2009; Saftner et al., 2006).

When evaluating optimal harvest time, this research suggests that following traditional harvest indicators developed for 
nongrafted watermelons may not be appropriate for grafted watermelon. This current study suggests that fruit quality of grafted watermelon at our study site was optimized when harvest was delayed $7 \mathrm{~d}$ after fruit were physiologically mature. Thus, reports of reduced fruit quality of grafted watermelon may not be an attribute imparted from the grafting process; rather, reduced quality may be a factor of improper (early) harvest timing (Soteriou et al., 2014). Simultaneous harvest of grafted and self-rooted plants assumes a synchronized maturation, which overlooks the effect of grafting on fruit ripening behavior (Davis et al., 2008). Our study found that while individual watermelon fruit weight and TSS increased by delaying harvest by $14 \mathrm{~d}$, the fruit firmness decreased. Grafted watermelon harvested $7 \mathrm{~d}$ after traditional harvest indicators were present had slightly heavier fruit (compared with $0 \mathrm{~d}$ harvest) with no impact on fruit firmness, TSS, hollow heart or number of hard seeds and also had increased lycopene content compared with harvest at 0 and $14 \mathrm{~d}$. Other research studies have shown that environmental conditions, such as soil fertility, irrigation, light intensity, and day/ night temperatures, as well as harvest maturity and vine health, can affect lycopene formation, development, and stability in watermelon (Naz et al., 2014; Perkins-Veazie et al., 2001). Our findings help reinforce the conclusion of a delayed harvest for grafted watermelon by Soteriou et al. (2014) and the anecdotal evidence presented by Roberts et al. (2007), which states: "We have reason to believe that grafting may also influence the days from planting until harvest. It is possible that grafting may delay the harvest date by about $7 \mathrm{~d}$, and this delayed maturity may be affecting yield, fruit firmness, fruit sugar, and perhaps fruit lycopene. We have not done enough research on this subject to definitively give answers to all of those questions.'

Overall, from the current study, it can be concluded that grafting watermelon using the splice grafting method where both cotyledons are removed could significantly decrease grafting costs because it would eliminate the need for extra attention and time when cutting the watermelon rootstock for grafting. In addition, rootstock regrowth would be eliminated because the rootstock meristem tissue would be removed when both cotyledons are removed. This could reduce the cost of grafted watermelon transplants, which could help increase the adoption of grafted watermelon plants in the United States. Furthermore, watermelon fruit yield and quality from splice-grafted plants is the same as for the traditional grafting method. However, when harvesting any grafted watermelons, timing of maturation to optimize fruit quality needs to be considered and can be achieved through a 7-day delayed harvest. Furthermore, we recommend that a comprehensive, internationally accepted naming system be used to standardize grafting method terminology, so that it is clear there is a distinction between splice grafting where both cotyledons are removed and one-cotyledon grafting.

\section{Literature Cited}

AgriMet, Pacific Northwest Region. 2019. Cooperative agricultural weather network, Pacific Northwest region. 14 Sept. 2019. <https:// www.usbr.gov/pn/agrimet/links.html>.

Aldasoro, J., E. Larrainzar, and C. Arrese-Igor. 2019. Application of antitranspirants temporarily alleviates the inhibition of symbiotic nitrogen fixation in drought-stressed pea plants. Agr. Water Mgt. 213:193-199.

Atkinson, C.J. and M.A. Else. 2001. Understanding how rootstocks dwarf fruit trees. Proc. Compact Fruit Tree 34(2):46-49. 10 Mar. 2019. $<$ https://www.researchgate.net/profile/Christopher_Atkinson/publication/285684959_Understanding_how_rootstocks_dwarf_fruit_trees links/566ade5c08ae62b05f045138.pdf>.

Barrett, C., X. Zhao, and A. Hodges. 2012. Cost benefit analysis of using grafted transplants for root-knot nematode management in organic heirloom tomato production. HortTechnology 22:252-257.

Bisognin, D.A., L. Velasquez, and I. Widders. 2005. Cucumber seedling dependence on cotyledonary leaves for early growth. Pesqui. Agropecu. Bras. 40:531-539.

Bruton, B.D., W.W. Fish, W. Roberts, and T.W Popham. 2009. The influece of rootstock selection on fruit quality attributes of watermelon. Open Food Sci. J. 3:15-34.

Buller, S., D. Inglis, and C. Miles. 2013. Plant growth, fruit yield and quality, and tolerance to verticillium wilt of grafted watermelon and tomato in field production in the Pacific Northwest. HortScience 48:1-7.

Camacho, F., M. Ricardez, and M.V. Huitron. 2011. Watermelon and melon grafting in Colima, Mexico as an alternative to soil disinfection with methyl bromide. Acta Hort 898:265-269.

Choi, D.C., S.W. Kwon, B.R. Ko, and J.S. Choi. 2002. Using chemical controls to inhibit axillary buds of Lagenaria as rootstock for grafted watermelon (Citrullus lanatus). Acta Hort. 588:43-48.

Colla, G., C.M.C. Suarez, M. Cardarelli, and Y Rouphael. 2010. Improving nitrogen use efficiency in melon by grafting. HortScience 45:559-565.

Dabirian, S. and C.A. Miles. 2017a. Increasing survival of splice-grafted watermelon seedlings using a sucrose application. HortScience 52:579-583

Dabirian, S. and C.A. Miles. 2017b. Antitranspirant application increases grafting success of watermelon. HortTechnology 52:579-583.

Dabirian, S., D. Inglis, and C. Miles. 2017. Grafting watermelon and using plastic mulch to control verticillium wilt caused by Verticillium dahliae in Washington. HortScience 52:349-356.

Daley, S.L. and R.L. Hassell. 2014. Fatty alcohol application to control meristematic regrowth in bottle gourd and interspecific hybrid squash rootstocks used for grafting watermelon. HortScience 49:260-264.

Davis, A.R. and P. Perkins-Veazie. 2005. Rootstock effects on plant vigor and watermelon fruit quality. Cucurbit Genet. Coop. Rpt. 28-29: 39-41.27 Oct. 2019. <http://cuke.hort.ncsu.edu/ cgc/cgc2829/cgc2829-11.pdf>.

Davis, A.R., P. Perkins-Veazie, Y. Sakata, S. López- Galarza, J.V. Maroto, S.G. Lee, Y.C. Huh, A. Miguel, S.R. King, R. Cohen, and Y.M. Lee. 2008. Cucurbit grafting. Crit. Rev. Plant Sci. 27:50-74.
Del Amor, F., P. Cuadra-Crespo, D. Walker, J.M. Cámara-Zapata, and R. Madrid. 2010. Effect of foliar application of antitranspirant on photosynthesis and water relations of pepper plants under different levels of $\mathrm{CO} 2$ and water stress. J. Plant Physiol. 167:1232-1238.

Devi, P. and C. Miles. 2018. Effect of antitranspirant application on the survival of splice-grafted watermelon. HortScience 53:S356 (abstr.).

Devi, P. and C. Miles. 2020. Increasing survival and efficacy of splice-grafted watermelon using sucrose and antitranspirant. Proc. Acta Hort. (in press).

Food and Agriculture Organization of the United Nations. 2012. The state of food and agriculture. 21 Feb. 2020. <http://www.fao.org/3/ai3028e.pdf $>$.

Fernandez-Garcia, N., M. Carvajal, and E. Olmos. 2004. Graft union formation in tomato plants: Peroxidase and catalase involvement. Ann. Bot. 93:53-60.

Fredes, A., S. Roselló, J. Beltrán, J. CebollaCornejo, A. Pérez-de-Castro, C. Gisbert, and M.B. Picó. 2017. Fruit quality assessment of watermelons grafted onto citron melon rootstock. J. Sci. Food Agr. 97:1646-1655.

Georgia Vegetable Team. 2000. Commercial watermelon production. Univ. Ga. Coop. Ext. Serv. Bul. 996.V. 15 Mar. 2019. <https://secure.caes. uga.edu/extension/publications/files/pdf/B \%20996_4.PDF>.

Grill, E. and H. Ziegler. 1998. A plants dilemma. Science 282:252-253.

Guan, W. 2019. How to splice graft cucumber plants. Purdue Univ. Ext. Pub. HO-328-W. 14 Sept. 2019. <https://www.extension.purdue.edu/ extmedia/HO/HO-328-W.PDF>.

Guan, W. and X. Zhao. 2015. Effects of grafting methods and root excision on growth characteristics of grafted muskmelon plants. HortTechnology 25:706-713.

Hassell, R.L., F. Memmott, and D.G. Liere. 2008. Grafting methods for watermelon production. HortScience 43:1677-1679.

Hetherington, A. 1998. Plant physiology: Spreading a drought warning. Curr. Biol. 8(25):911-913.

Hunter, J.J., C.G. Volschenk, D.J. le Roux, and L. Adams. 2004. Plant material quality: A compilation of research. ARC Infruitec-Nietvoorbij, Stellenbosch, South Africa. 28 Sept. 2019 $<$ http://www.winetech.co.za/documents/plantmaterial/plantmaterialquality.pdf $>$.

Johnson, G. 2012. Can Antitranspirants and Antidesiccants Improve Vegetable Transplant Survival? Weekly Crop Update, University of Delaware Cooperative Extension. 15 Mar. 2019. $<$ https://agdev.anr.udel.edu/weeklycropupdate/? $\mathrm{p}=3942>$.

Johnson, S.J. and C.A. Miles. 2011. Effect of healing chamber design on the survival of grafted eggplant, tomato, and watermelon. HortTechnology 21:752-758.

King, S.R., A.R. ,Davis W. Liu, and A. Levi. 2008. Grafting for Disease Resistance. HortScience 43:1673-1676.

Kubota, C., M.A. McClure, N. Kokalis-Burelle, M.G. Bausher, and E.N. Rosskopf. 2008. Vegetable grafting: History, use and current technology status in North America. HortScience 43:1664-1669.

Kyriacou, M.C., Y. Rouphael, G. Colla, R. Zrenner, and D. Schwarz. 2017. Vegetable grafting: The implications of a growing agronomic imperative for vegetable fruit quality and nutritive value. Front. Plant Sci. 8:741.

Lee, J.M. and M. Oda. 2003. Grafting of herbaceous vegetable and ornamental crops. Hort. Rev. 28:61-123.

Lee, J.M. and M. Oda. 2010. Grafting of herbaceous vegetable and ornamental crops. In: J. 
Janick (ed.). Horticultural Reviews, vol. 28. Wiley Online Library.

Louws, F.J., C.L. Rivard, and C. Kubota. 2010. Grafting fruiting vegetables to manage soilborne pathogens, foliar pathogens, arthropods and weeds. Scientia Hort. 127:127-146.

Melnyk, C.W. 2017. Monitoring vascular regeneration and xylem connectivity in Arabidopsis thaliana. Methods Mol. Biol. 1544:91-102.

Memmott, F. D. and R. L. Hassell. 2010. Watermelon (Citrullus lanatus) grafting method to reduce labor cost by eliminating rootstock side shoots. Acta Hort. 871:389-394 (abstr.).

Miles, C., L. Hesnault, S. Johnson, P. Kreider, and S. Dabirian. 2016. Vegetable grafting: Watermelon. Wash. State Univ. Ext. Pub FS100E.

Miles, C., P. Devi, X. Zhao, and W. Guan. 2017. Chapter 3.2.1. Watermelon and melon grafting. In: C. Kubota, C. Miles and X. Zhao (eds.). Grafting manual: How to produce grafted vegetable plants. 18 Sept. 2019. <http://www.vegetablegrafting. org/resources/grafting-manual/>.

Mohamed, F.H., K.E. Abd El-Hamed, M.W.M. Elwan, and M.N.E. Hussien. 2014. Evaluation of different grafting methods and rootstocks in watermelon grown in Egypt. Scientia Hort. 168:145-150.

Naz, A., M.S. Butt, M.T. Sultan, M.N. Qayyum, and R.S. Niaz. 2014. Watermelon lycopene and allied health claims. EXCLI J. 13:650-666. 14 Oct. 2019.<https://www.ncbi.nlm.nih.gov/pmc/ articles/PMC4464475/pdf/EXCLI-13-650.pdf>.

Nitzsche, P., G.A. Berkowitz, and J. Rabin. 1991. Development of a seedling applied antitranspirant formulation to enhance water status, growth, and yield of transplanted bell pepper. J. Amer. Soc. Hort. Sci. 116:405-411.

Oda, M. 2007. Vegetable grafting in Japan. In: J. Janick (ed.). Proc. XXVII IHC on Global Hort.: Diversity and Harmony. Acta Hort 759:175-180.
Ogata, T., Y. Kabashima, S. Shiozaki, and S. Horiuchi. 2005. Regeneration of the vascular bundle at the graft interface in auto- and heterografts with juvenile nucellar seedlings of satsuma mandarin, yuzu and trifoliate orange. J. Jpn. Soc. Hort. Sci. 74:214-220.

Perkins-Veazie, P., J.K. Collins, S.D. Pair, and W. Roberts. 2001. Lycopene content differs among red-fleshed watermelon cultivars. J. Sci. Food Agr. 81:1-5.

Proietti, S., Y. Rouphael, G. Colla, M. Cardarelli, M. De Agazio, M. Zacchini, E. Rea, S. Moscatello, and A. Battistelli. 2008. Fruit quality of miniwatermelon as affected by grafting and irrigation regimens. J. Sci. Food Agr. 88:1107-1114.

Ricárdez-Salinas, M., M.V. Huitrón-Ramírezb, J.C. Tello-Marquinac, and F. Camacho-Ferre. 2010. Planting density for grafted melon as an alternative to methyl bromide use in Mexico. Scientia Hort. 126(2):236-241.

Rivard, C. and F.J. Louws. 2006. Grafting for disease resistance in heirloom tomatoes. North Carolina State Univ. Coop. Ext. Serv. 675. 11 Mar. 2019. <https://content.ces.ncsu.edu/ grafting-for-disease-resistance-in-heirloomtomatoes>.

Rivard, C.L., O. Sydorovych, S. O'Connell, M.M. Peet, and F.J. Louws. 2010. An economic analysis of two grafted tomato transplant production systems in the United States. HortTechnology 20:794-803.

Roberts, W., B. Bruton, W. Fish, and M. Taylor. 2007. Using grafted transplants in watermelon production. Proc. Southeast Reg. Veg. Conf. (Ed. WT Kelley), Savannah, GA, USA. 20 Oct. 2019. $<$ https://www.researchgate.net/profile/Wayne Fish/publication/268346495_USING_GRAFTED_ TRANSPLANTS_IN_WATERMELON_PRODUCTION/links/54bb95d90cf253b50e2d0fe1.pdf .

Rouphael, Y., D. Schwarz, A. Krumbein, and G. Colla. 2010. Impact of grafting on product quality of fruit vegetables. Scientia Hort. 127: $172-179$.

Saftner, R., J.A. Abbott, G. Lester, and B. Vinyard. 2006. Sensory and analytical comparison of orange-fleshed honeydew to cantaloupe and green-fleshed honeydew for fresh-cut chunks. Postharvest Biol. Technol. 42:150 160.

Shirai, T. and M. Hagimori. 2004. Studies in establishment of transplant production methods of sweet pepper (Capsicum annuиm L.) by grafting shoots harvested from mother plants: Effect of healing conditions of grafts on the rate and quality of successful union. J. Jpn. Soc. Hort. Sci. 73:380-385. 21 Sept. 2019. <https:// www.jstage.jst.go.jp/article/jjshs1925/73/4/73_4_ 380/_pdf $>$.

Soteriou, G.A., M.C. Kyriacou, A.S. Siomos, and D. Gerasopoulos. 2014. Evolution of watermelon fruit physicochemical and phytochemical composition during ripening as affected by grafting. Food Chem. 165:282-289.

Taylor, M., B. Bruton, W. Fish, and W. Roberts. 2008. Cost benefit analysis of using grafted watermelon transplants for fusarium wilt disease control. Acta Hort. 782:343-350.

Wimer, J.A., C.A. Miles, and D.A. Inglis. 2015. Evaluating grafted watermelon for verticillium wilt severity, yield, and fruit quality in Washington State. HortScience 50:1332-1337.

Yetisir, H., N. Sari, and S. Yucel. 2003. Rootstock resistance to fusarium wilt and effect on watermelon fruit yield and quality. Phytoparasitica 31:163-169.

Yetisir, H. and F. Karaca. 2018. assessment of rooting capability and rootstock potentials of some turkish bottle gourd (Lagenaria siceraria) accessions used as rootstocks for watermelon [Citrullus lanatus (Thunb.) Matsum. \& Nakai]. Asian Res. J. Agr. 9(1): $1-10$. 